\title{
Solubility and Dissolution in Terms of Generalized Approach to Electrolytic Systems Principles
}

\author{
Anna Maria Michałowska-Kaczmarczyk ${ }^{1}$, Tadeusz Michałowski2*, \\ Marcin Toporek $^{2}$, Andrzej Pietrzyk ${ }^{2}$ \\ ${ }^{1}$ Department of Oncology, The University Hospital in Cracow, Cracow, Poland \\ ${ }^{2}$ Department of Analytical Chemistry, Technical University of Cracow, Cracow, Poland \\ Email: *michalot@o2.pl
}

Received 22 October 2015; accepted 11 December 2015; published 14 December 2015

Copyright @ 2015 by authors and Scientific Research Publishing Inc.

This work is licensed under the Creative Commons Attribution International License (CC BY). http://creativecommons.org/licenses/by/4.0/

c) (7) Open Access

\section{Abstract}

The correct approach, based on the rules of conservation and detailed physicochemical/thermodynamic knowledge on the system considered is opposed to conventional approach to solubility and dissolution, based on stoichiometry of a reaction notation and on the solubility product $\left(K_{s p}\right)$ of a precipitate. The correct approach is realized according to Generalized Approach to Electrolytic Systems (GATES) principles, with use of iterative programs applied for computational purposes. All the qualitative and quantitative knowledge is involved in the balances and independent expressions for the equilibrium constants. Three two-phase electrolytic systems with diversified chemical properties were selected carefully, from the viewpoint of their diversity. The results of calculations are presented graphically and discussed. The advantages of the GATES in resolution of two-phase (static) non-redox systems and one complex (dynamic) redox system are proved.

\section{Keywords}

Solubility, Dissolution, GATES

\section{Introduction}

The problem of solubility of chemical compounds occupies a prominent place in the scientific literature. This stems from the fact that among various properties determining the use of these compounds, the solubility is one of paramount importance. The distinguishing feature of a sparingly soluble (hydr) oxide [1] or a salt, is the solu-

${ }^{*}$ Corresponding author.

How to cite this paper: Michałowska-Kaczmarczyk, A.M., Michałowski, T., Toporek, M. and Pietrzyk, A. (2015) Solubility and Dissolution in Terms of Generalized Approach to Electrolytic Systems Principles. Journal of Analytical Sciences, Methods and Instrumentation, 5, 47-58. http://dx.doi.org/10.4236/jasmi.2015.54006 
bility product $\mathrm{K}_{\mathrm{sp}}$ value of this precipitate. However, it is not the only parameter defining the real solubility $\mathrm{s}$ [mol/L] of the precipitate in two-phase system. Such "simplifications" made e.g. in [2], are unacceptable and give incorrect results, as proved in [3]-[6]. These objections, formulated in the light of the GATES [7], are presented also in the current paper, related to two static non-redox systems, and one dynamic redox system.

The systems with three precipitates considered in details herein, namely: nickel dimethylglyoximate $\left(\mathbf{N i L}_{2}\right)$, struvite $\left(\mathbf{M g N H}_{4} \mathbf{P O}_{4}\right)$ and copper (I) iodide (CuI), considered, illustrate different behavior of the solid phases in the related media. All soluble species formed by ions constituting a precipitate are involved in expression for solubility of the precipitates. $\mathrm{NiL}_{2}$ is considered in context with gravimetric analysis of $\mathrm{Ni}^{2+}$ ions when treated with an excess of precipitating agent. The contact of struvite with pure water or $\mathrm{CO}_{2}$ solution imitates the washing stage; it is stated that the struvite is not an equilibrium solid phase in the related systems. The solubility of CuI present in the system in two consecutive stages of four-stage titrimetric procedure is affected also by the components formed on earlier stages of this procedure.

\section{Solubility and Dissolution}

\subsection{Preliminary Remarks Related to the Solubility Concept}

One can consider two consecutive steps justifying calculation of the solubility of precipitates. This calculation is important from the viewpoint of gravimetry, where quantitative transformation of an analyte into sparingly soluble precipitate occurs. These steps are involved with 1) an excess of the precipitating agent added; 2) removing of this excess and of some other soluble species after washing the precipitate. Realization of the second step is practically equivalent to the addition of an excess of the precipitate into pure water.

The precipitates will be denoted below in bold letters.

The precipitation and further analytical operations made in gravimetric analyses (filtration, washing) are usually carried out at temperatures ca. $60^{\circ} \mathrm{C}-80^{\circ} \mathrm{C}$, i.e., far greater than the room temperature, at which the equilibrium constants values, known from the literature data, were determined, and then applied in calculations. On both steps, the solubility s [mol/L] of the precipitate should be considered as the sum of concentrations of all soluble species formed by the analyte in the liquid phase (solution). However, the results thus obtained may be helpful in the choice of optimal a priori conditions of the analysis, ensuring minimal solubility of the precipitate.

In literature, e.g. [2] [8] [9], and in numerous educational links offered in Internet networks [10] devoted to equilibria with a solid phase involved, one can prevalently find the approach to the calculation of solubility ( $\mathrm{s}^{*}$, $\mathrm{mol} / \mathrm{L}$ ) of pure precipitate when introduced in excess into pure water; this approach is based on the stoichiometric reaction notation, involved with dissociation of the precipitate. Thus for $\mathbf{A}_{\mathbf{a}} \mathbf{B}_{\mathbf{b}}=\mathrm{aA}+\mathrm{bB}$, we have

$$
s^{*}=\left(\frac{K_{s p}}{a^{a} \cdot b^{b}}\right)^{1 /(a+b)}
$$

and for $\mathbf{A}_{\mathbf{a}} \mathbf{B}_{\mathbf{b}} \mathbf{C}_{\mathbf{c}}=\mathrm{aA}+\mathrm{bB}+\mathrm{cC}$, we have

$$
s^{*}=\left(\frac{K_{s p}}{a^{a} \cdot b^{b} \cdot c^{c}}\right)^{1 /(a+b+c)}
$$

That approach was widely criticized in [11].

As a rule, Equations (1) and (2) are invalid for different reasons. This invalidity results, among others, from inclusion of minor species in Equations (1) and (2); other soluble species formed by A and B are thus omitted. In other words, not only the species entering the expression for the related solubility product are present in the solution considered.

As indicated e.g. in [12], different solid phases may be formed in the system in question, depending on $\mathrm{pH}$ of the solution. This raises further, serious problems involved with calculating of the solubility s* value. Namely, in Equation (1) or (2) it is assumed, that a solution formed after introducing a precipitate into pure water is saturated with respect to this precipitate; this fundamental requirement is not often fulfilled. For example, pure struvite $\mathbf{M g N H}_{4} \mathbf{P O}_{4}$ when introduced into pure water is not the equilibrium solid phase [13]. This effect, confirmed by evolution of ammonia on the step of washing this precipitate with water [14], can be explained by the reaction [13]. 


$$
3 \mathbf{M g N H}_{4} \mathbf{P O}_{4}=\mathbf{M g}_{3}\left(\mathbf{P O}_{4}\right)_{2}+\mathrm{HPO}_{4}^{2-}+\mathrm{NH}_{3}+2 \mathrm{NH}_{4}^{+}
$$

Therefore, the formula $\mathrm{s}^{*}=\left(\mathrm{K}_{\mathrm{sp}}\right)^{1 / 3}$, obtained from Equation (2) at a $=\mathrm{b}=\mathrm{c}=1$ and related to

$$
\mathbf{M g N H}_{4} \mathbf{P O}_{4}=\mathrm{Mg}^{2+}+\mathrm{NH}_{4}^{+}+\mathrm{PO}_{4}^{3-} \rightarrow \mathrm{K}_{\mathrm{sp}}=\left[\mathrm{Mg}^{2+}\right]\left[\mathrm{NH}_{4}^{+}\right]\left[\mathrm{PO}_{4}^{3-}\right]
$$

is inapplicable for calculation of solubility of struvite, for the reasons specified above. Nonetheless, it is still quoted in different papers, e.g. [15] [16], and Internet [17].

\subsection{Solubility of Nickel Dimethyglyoximate ( $\left.\mathrm{NiL}_{2}\right)$}

In an immediate experimental option, nickel dimethylglyoximate $\mathbf{N i L}_{2}\left(=\mathrm{C}_{8} \mathrm{H}_{14} \mathrm{~N}_{4} \mathrm{O}_{4} \mathrm{Ni}\right.$, named commonly as nickel dimethylglyoxime, see e.g. [18] [19]) is precipitated after addition of an excess of dimethylglyoxime (HL $\left.=\mathrm{CH}_{3} \mathrm{C}(\mathrm{NOH}) \mathrm{C}(\mathrm{NOH}) \mathrm{CH}_{3}\right)[20]$ into $\mathrm{Ni}^{2+}$ solution with ammonia buffer. Protons liberated in reaction $\mathrm{Ni}^{2+}+$ $2 \mathrm{HL}=\mathrm{NiL}_{2}+2 \mathrm{H}^{+}$are bound in reaction $\mathrm{NH}_{3}+\mathrm{H}^{+}=\mathrm{NH}_{4}^{+}$; the buffer pair $\mathrm{NH}_{4}^{+} / \mathrm{NH}_{3}$ added in excess gives pH ca. 9 - 9.5, as a rule. In analytical practice, another manner of $\mathbf{N i L}_{2}$ precipitation is applied [21].

A remark. The term: nickel dimethylglyoxime is incorrect. Dimethylglyoxime is the name of the precipitating reagent and $\mathbf{N i L}_{2}$ is the salt. The names of the salts are formed by addition of ending -ate to the cores of oxyacids, e.g. copper oxyquinolinate [22], or more properly as copper 8-quinolate [23]. The name copper 8-hydroxyquinoline [24] is not correct, too; $\mathrm{Cu}^{2+}$ replaces here two protons from -OH groups of two molecules of 8-hydroxyquinoline. Copper 8-hydroxyquinoline is not a synonym for properly written terms: bis(8-oxyquinoline)copper, copper oxinate [24]; oxine is the shortest name of 8-hydroxyquinoline [25]. Compare with sulfate, nitrate.

The logs vs. $\mathrm{pH}$ relationships presented in Figure 1, refer to the systems with $\mathrm{C}_{\mathrm{Ni}} \mathrm{mol} / \mathrm{L} \mathrm{NiSO} \mathrm{N}_{4}$ and other components indicated in the legend. The plots refer to the equilibrium data taken from [26], related to room temperature. The soluble Ni-species enter the formula

$$
\mathrm{s}=\mathrm{s}_{\mathrm{Ni}}=\left[\mathrm{Ni}^{2+}\right]+\left[\mathrm{NiOH}^{+}\right]+\left[\mathrm{NiSO}_{4}\right]+\left[\mathrm{NiCH}_{3} \mathrm{COO}^{+}\right]+\sum_{\mathrm{i}=0}^{2}\left[\mathrm{NiH}_{\mathrm{i}} \mathrm{Ci}^{+\mathrm{i}-2}\right]+\sum_{\mathrm{i}=1}^{6}\left[\mathrm{Ni}\left(\mathrm{NH}_{3}\right)_{\mathrm{i}}^{2+}\right]+\left[\mathrm{NiL}_{2}\right]
$$

for the solubility s of $\mathbf{N i L}_{2}$ and ascribed to the curve c in Figure 1, where $\mathrm{H}_{4} \mathrm{Ci}$-citric acid. At equilibrium we have: $\left[\mathrm{NiL}_{2}\right]=\mathrm{K}_{2} \cdot\left[\mathrm{Ni}^{2+}\right]\left[\mathrm{L}^{-}\right]^{2}=\mathrm{K}_{2} \cdot \mathrm{K}_{\mathrm{sp}}$, where $\mathrm{K}_{2}=10^{17.24}, \mathrm{~K}_{\mathrm{sp}}=\left[\mathrm{Ni}^{2+}\right]\left[\mathrm{L}^{-}\right]^{2}=10^{-23.66}[5][6]$, and then $\left[\mathrm{NiL}_{2}\right]=$ $10^{-6.42}$ (i.e., $\log \left[\mathrm{NiL}_{2}\right]=-6.42$ ). The $\left[\mathrm{NiL}_{2}\right]$ value is the limiting component in expression for the solubility $\mathrm{s}$ of $\mathrm{NiL}_{2}$ (Equation (5)), i.e. $\min \mathrm{s} \cong\left[\mathrm{NiL}_{2}\right]$. In context of Equation (5) with Figure 1, we see that the soluble complex $\mathrm{NiL}_{2}$ is the predominant species for $\mathrm{pH}>5.5$ (curves a and $\mathrm{b}$ ), and $\mathrm{pH}>8$ (curve c); i.e., the effect of Ni$\mathrm{H}_{\mathrm{i}} \mathrm{Cit}^{+\mathrm{i}-2}$ species on the s-value is negligible in ammonia buffer media.

Calculations of solubility s were made here at $\mathrm{C}_{\mathrm{Ni}}=0.001 \mathrm{~mol} / \mathrm{L}$ and $\mathrm{C}_{\mathrm{L}}=0.003 \mathrm{~mol} / \mathrm{L} \mathrm{HL}$, i.e., at the excessive HL concentration equal $\mathrm{C}_{\mathrm{L}}-2 \mathrm{C}_{\mathrm{Ni}}=0.001 \mathrm{~mol} / \mathrm{L}$. Solubility of $\mathrm{HL}$ in water, equal $0.063 \mathrm{~g} \mathrm{HL} / 100 \mathrm{~mL} \mathrm{H}_{2} \mathrm{O}$ $\left(25^{\circ} \mathrm{C}\right)$ [27], corresponds to concentration $0.63 / 116.12=0.0054 \mathrm{~mol} / \mathrm{L}$ of the saturated HL solution, $0.003<$

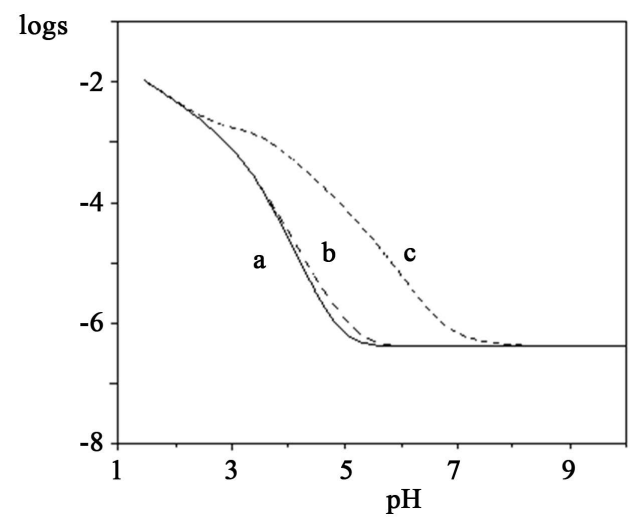

Figure 1. The solubility (s, Equation (1)) curves for nickel dimethylglyoximate $\mathrm{NiL}_{2}$ in (a) Ammonia; (b) Acetate + ammonia; (c) Citrate + acetate + ammonia media at total concentrations $[\mathrm{mol} / \mathrm{L}]: \mathrm{C}_{\mathrm{Ni}}=0.001, \mathrm{C}_{\mathrm{L}}=0.003, \mathrm{C}_{\mathrm{N}}=0.5, \mathrm{C}_{\mathrm{Ac}}=0.3, \mathrm{C}_{\mathrm{Ci}}=0.1$. 
0.0054. Applying higher $C_{L}$ values, needs the HL solution in ethanol, where HL is fairly soluble. However, the aqueous-ethanolic medium is thus formed, where equilibrium constants are unknown. To avoid it, lower $\mathrm{C}_{\mathrm{Ni}}$ and $\mathrm{C}_{\mathrm{L}}$ values were applied in calculations.

\subsection{Dissolution of Struvite}

After introducing pr1 $=\mathbf{M g N H}_{4} \mathbf{P O}_{4}$ into water, at initial concentration of pr1 equal $\mathrm{C}_{0}=[\mathrm{pr} 1]_{\mathrm{t}=0}=10^{-3} \mathrm{~mol} / \mathrm{L}$ $\left(\mathrm{pC}_{0}=(\mathrm{ppr} 1)_{\mathrm{t}=0}=3\right.$; ppr1 $\left.=-\log [\mathrm{pr} 1]\right)$, the precipitation of $\mathrm{pr} 2=\mathbf{M g}_{3}\left(\mathbf{P O}_{4}\right)_{2}$ starts (Equation (3)) at ppr1 = 3.088; solubility products for other solids as pre-assumed precipitates are not crossed [13]. The expression for solubility s, in absence of carbonate species $\left(\mathrm{C}_{\mathrm{CO}_{2}}=0\right.$, i.e., $\left.\mathrm{pC}_{\mathrm{CO}_{2}}=\infty\right)$,

$$
\begin{aligned}
\mathrm{s}=\mathrm{s}_{\mathrm{Mg}}= & {\left[\mathrm{Mg}^{2+}\right]+\left[\mathrm{MgOH}^{+}\right]+\left[\mathrm{MgH}_{2} \mathrm{PO}_{4}^{+}\right]+\left[\mathrm{MgHPO}_{4}\right]+\left[\mathrm{MgPO}_{4}^{-}\right] } \\
& +\left[\mathrm{MgNH}_{3}^{2+}\right]+\left[\mathrm{Mg}\left(\mathrm{NH}_{3}\right)_{2}^{2+}\right]+\left[\mathrm{Mg}\left(\mathrm{NH}_{3}\right)_{3}^{2+}\right]
\end{aligned}
$$

involving all soluble magnesium species, is identical in its form, irrespectively on the equilibrium solid phase(s) present in this system. Moreover, it is stated that $\mathrm{pH}$ of the solution equals ca. 9 - 9.5 (Figure 5 in [13]); this $\mathrm{pH}$ can be affected by the presence of $\mathrm{CO}_{2}$ from air, i.e., at $\mathrm{C}_{\mathrm{CO}_{2}}>0$. Under such conditions, $\mathrm{NH}_{4}{ }^{+}$and $\mathrm{NH}_{3}$ are at comparable concentrations, $\left[\mathrm{NH}_{4}^{+}\right] \approx\left[\mathrm{NH}_{3}\right]$, but $\left[\mathrm{HPO}_{4}^{2-}\right] /\left[\mathrm{PO}_{4}^{3-}\right]=10^{12.36-\mathrm{pH}} \approx 10^{3}$. This way, the scheme $\mathbf{M g N H}_{4} \mathbf{P O}_{4}=\mathrm{Mg}^{2+}+\mathrm{NH}_{3}+\mathrm{HPO}_{4}^{2-}$ would be more advantageous than one given by Equation (4), with $\mathrm{K}_{\mathrm{sp}}^{*}=\left[\mathrm{Mg}^{2+}\right]\left[\mathrm{NH}_{3}\right]\left[\mathrm{HPO}_{4}^{2-}\right]=\mathrm{K}_{\mathrm{sp}} \mathrm{K}_{1 \mathrm{~N}} / \mathrm{K}_{3 \mathrm{P}}$, provided that struvite is the equilibrium solid phase; but it is not the case, see above; $\mathrm{K}_{1 \mathrm{~N}}=\left[\mathrm{H}^{+}\right]\left[\mathrm{NH}_{3}\right] /\left[\mathrm{NH}_{4}^{+}\right], \mathrm{K}_{3 \mathrm{P}}=\left[\mathrm{H}^{+}\right]\left[\mathrm{PO}_{4}^{3-}\right] /\left[\mathrm{HPO}_{4}^{2-}\right]$.

The reaction 3 occurs also in presence of $\mathrm{CO}_{2}$ in water, where struvite was introduced;

$\left[\mathrm{H}_{2} \mathrm{CO}_{3}\right]+\left[\mathrm{HCO}_{3}^{-}\right]+\left[\mathrm{CO}_{3}^{2-}\right]+\left[\mathrm{MgHCO}_{3}^{+}\right]+\left[\mathrm{MgCO}_{3}\right]=\mathrm{C}_{\mathrm{CO}_{2}}$. Struvite is the equilibrium solid phase only at a due excess of at least one of the precipitating reagents [13] [28] [29]. It was noticed that the system obtained after mixing magnesium, ammonium and phosphate salts at the molar ratio 1:1:1 contains an excess of ammonium species in the solution and the precipitate that "was not struvite, but was probably composed of magnesium phosphates" [14] was obtained; it confirms the data obtained from [13]. Such inferences were formulated on the basis of X-ray diffraction (XRD) [30]-[32] of the crystallographic structure of the solid phase thus obtained. This remark is important in context with gravimetric analysis of magnesium as pyrophosphate [13].

The behavior of the system can be formulated on the basis of formulas similar to those presented in [13] and referring to the system where pure pr1 is introduced into aqueous solution with dissolved $\mathrm{CO}_{2}\left(\mathrm{C}_{\mathrm{CO}_{2}} \mathrm{~mol} / \mathrm{L}\right)+$ $\mathrm{KOH}\left(\mathrm{C}_{\mathrm{b}} \mathrm{mol} / \mathrm{l}\right)$; initial $(\mathrm{t}=0)$ concentration of $\mathbf{M g N H}_{4} \mathbf{P O}_{4}$ in the system equals $\mathrm{C}_{0} \mathrm{~mol} / \mathrm{L}$. We apply here the notations [13]:

pr1 $=\mathbf{M g N H}_{4} \mathbf{P O}_{4}, \operatorname{pr} 2=\mathbf{M g}_{3}\left(\mathbf{P O}_{4}\right)_{2}, \operatorname{pr} 3=\mathbf{M g H P O}_{4}, \operatorname{pr} 4=\mathbf{M g}(\mathbf{O H})_{2}, \operatorname{pr} 5=\mathbf{M g C O}_{3}$.

ppri $=-\log [$ pri], where pri - precipitate of $\mathrm{i}$-th kind $(\mathrm{i}=1, \ldots, 5)$ with molar concentration [pri]

$$
\begin{gathered}
\mathrm{q}_{1}=\left[\mathrm{Mg}^{2+}\right] \cdot\left[\mathrm{NH}_{4}^{+}\right] \cdot\left[\mathrm{PO}_{4}^{3-}\right] / \mathrm{K}_{\mathrm{sp} 1}, \mathrm{q}_{2}=\left[\mathrm{Mg}^{2+}\right]^{3} \cdot\left[\mathrm{PO}_{4}^{3-}\right]^{2} / \mathrm{K}_{\mathrm{sp} 2}, \mathrm{q}_{3}=\left[\mathrm{Mg}^{2+}\right] \cdot\left[\mathrm{HPO}_{4}^{2-}\right] / \mathrm{K}_{\mathrm{sp} 3}, \\
\mathrm{q}_{4}=\left[\mathrm{Mg}^{2+}\right] \cdot\left[\mathrm{OH}^{-}\right]^{2} / \mathrm{K}_{\mathrm{sp} 4}, \quad \mathrm{q}_{5}=\left[\mathrm{Mg}^{2+}\right] \cdot\left[\mathrm{CO}_{3}^{2-}\right] / \mathrm{K}_{\mathrm{sp} 5} \\
\mathrm{pC}_{0}=-\log \mathrm{C}_{0}, \quad \mathrm{pC}_{\mathrm{CO}_{2}}=-\log _{\mathrm{CO}_{2}}, \quad \mathrm{pC} \mathrm{b}_{\mathrm{b}}=-\log _{\mathrm{b}} .
\end{gathered}
$$

At $\left(\mathrm{pC}_{0}, \quad \mathrm{pC}_{\mathrm{CO}_{2}}, \mathrm{pC}_{\mathrm{b}}\right)=(2,2, \infty)$; after the solubility product for $\mathrm{pr} 3$ attained (line ab at ppr1 = 2.376), pr3 is the equilibrium solid phase up to ppr1 $=2.393$ (line cd), where the solubility product for pr2 is attained, see Figure 2 and Figure 3. For ppr1 $\in<2.393,2.506>$, two equilibrium solid phases (pr2 and pr3) exist in the system. Then, at ppr1 = 2.506 (line ef), pr3 is totally depleted, and then pr1 is totally transformed into pr2. At ppr1 > 2.506, only pr2 is the equilibrium solid phase. On particular steps, the following, predominating reactions occur:

$$
\begin{gathered}
\mathrm{pr} 1+2 \mathrm{H}_{2} \mathrm{CO}_{3}=\mathrm{Mg}^{2+}+\mathrm{NH}_{4}^{+}+\mathrm{H}_{2} \mathrm{PO}_{4}^{-}+2 \mathrm{HCO}_{3}^{-} \\
\mathrm{pr} 1+\mathrm{H}_{2} \mathrm{CO}_{3}=\mathrm{pr} 3+\mathrm{NH}_{4}^{+}+\mathrm{HCO}_{3}^{-}
\end{gathered}
$$




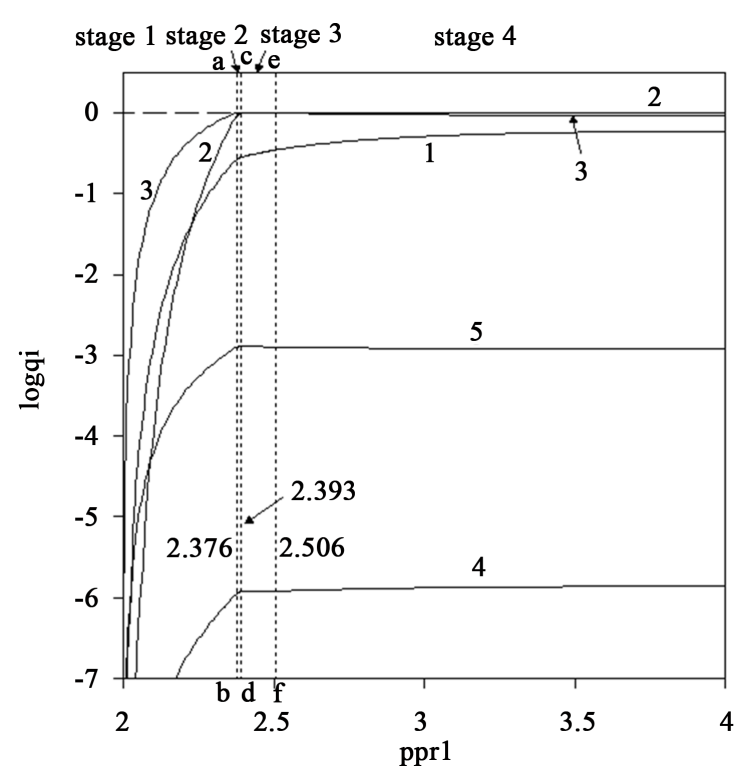

Figure 2. The $\log \mathrm{q}_{\mathrm{i}}$ vs. ppr1 relationships for different pri $(\mathrm{i}=1, \ldots, 5)$, at $\left(\mathrm{pC}_{0}, \mathrm{pC}_{\mathrm{CO}_{2}}, \mathrm{pC}_{\mathrm{b}}\right)=(2,2, \infty)$.

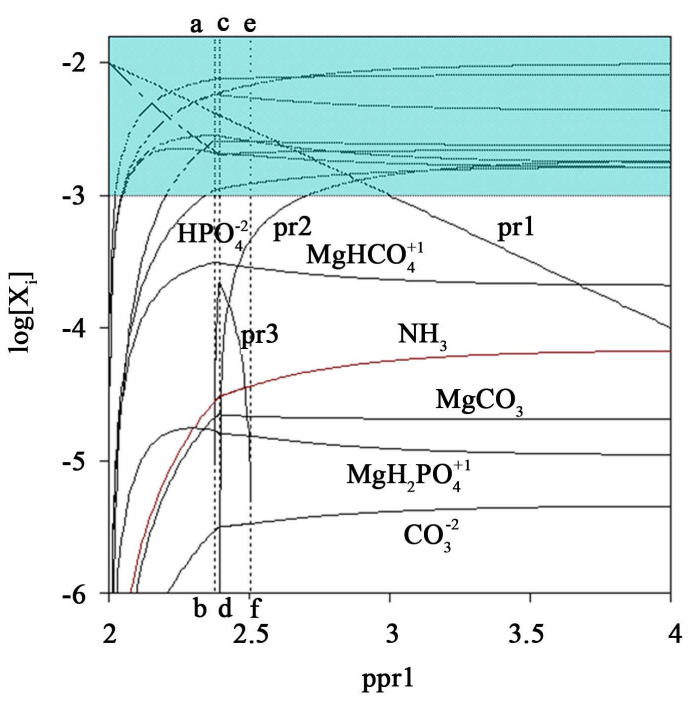

(a)

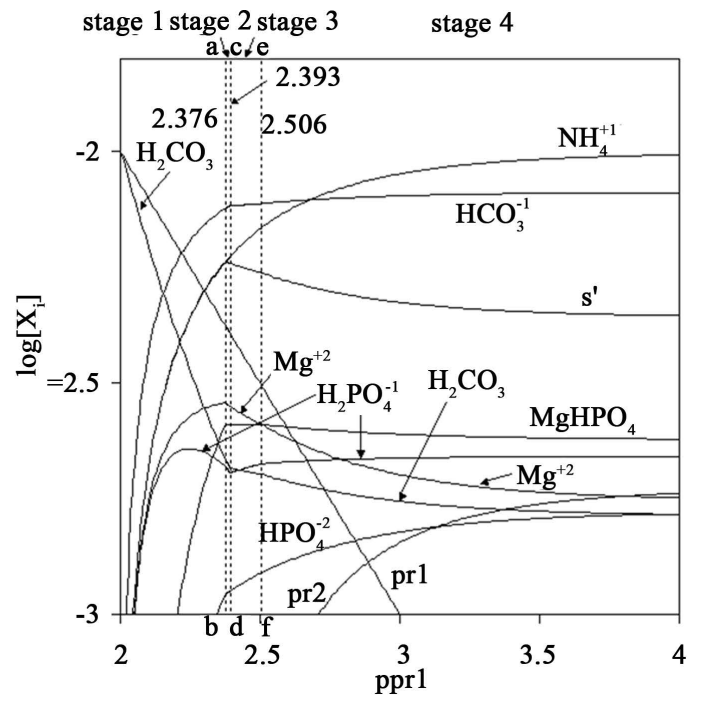

(b)

Figure 3. The $\log \left[\mathrm{X}_{\mathrm{i}}\right]$ vs. ppr1 relationships for indicated species $\mathrm{X}_{\mathrm{i}}$ at $\left(\mathrm{pC}_{0}, \mathrm{pC}_{\mathrm{CO}_{2}}, \mathrm{pC} \mathrm{C}_{\mathrm{b}}\right)=(2,2, \infty) ; \mathrm{C}_{\mathrm{b}}=-\log \mathrm{C}_{\mathrm{b}}$. (b) is a detailed part of (a); s' is defined by Equation (14).

$$
\begin{gathered}
\mathrm{pr} 1+2 \mathrm{pr} 3=\mathrm{pr} 2+\mathrm{NH}_{4}^{+}+\mathrm{H}_{2} \mathrm{PO}_{4}^{-} \\
3 \mathrm{pr} 1+2 \mathrm{H}_{2} \mathrm{CO}_{3}=\mathrm{pr} 2+3 \mathrm{NH}_{4}^{+}+\mathrm{H}_{2} \mathrm{PO}_{4}^{-}+2 \mathrm{HCO}_{3}^{-}
\end{gathered}
$$

The pH vs. ppr1 relationship is presented in Figure 4.

At $\left(\mathrm{pC}_{0}, \mathrm{pC}_{\mathrm{CO}_{2}}, \mathrm{pC}_{\mathrm{b}}\right)=(2,4,2)$, the dissolution process consists on three stages (Figure 5 and Figure 6 ). On the stage 1 , pr4 precipitates first

$$
\mathrm{pr} 1+2 \mathrm{OH}^{-}=\mathrm{pr} 4+\mathrm{NH}_{3}+\mathrm{HPO}_{4}^{2-}
$$

nearly from the very start of pr1 dissolution, up to ppr1 $=2.151$, where $\mathrm{K}_{\mathrm{sp} 2}$ for pr2 is attained. Within the stage 2 , the solution is saturated toward pr2 and pr4. On this stage, the reaction, expressed by the notation 


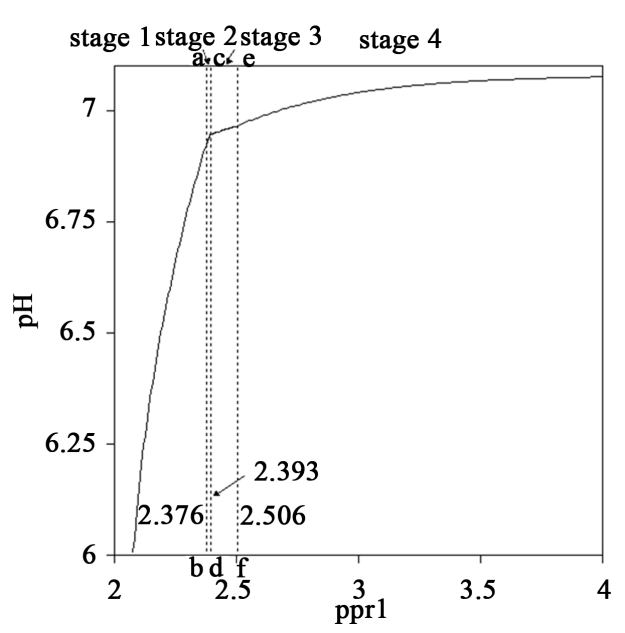

Figure 4. The $\mathrm{pH}$ vs. ppr1 relationships plotted at $\left(\mathrm{pC}_{0}, \mathrm{pC}_{\mathrm{CO}_{2}}, \mathrm{pC}_{\mathrm{b}}\right)=(2,2, \infty)$.

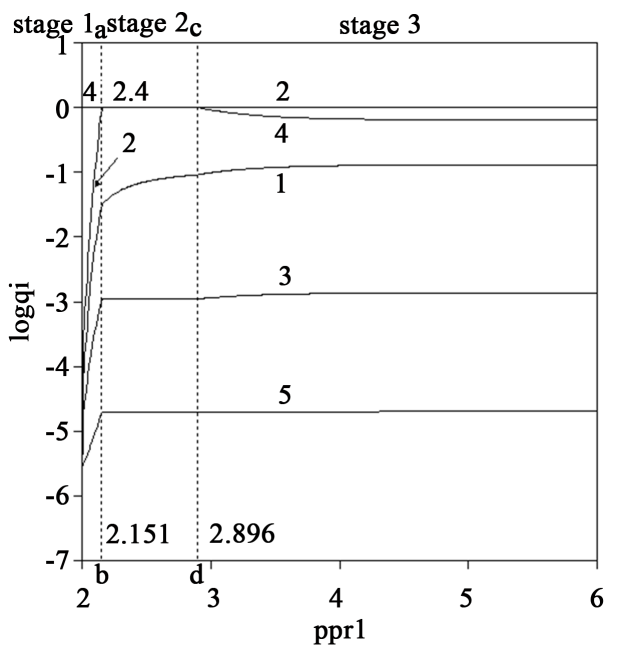

Figure 5. The $\log q_{i}$ vs. ppr1 relationships for different pri $(i=1, \ldots, 5)$, at $\left(\mathrm{pC}_{0}, \quad \mathrm{pC}_{\mathrm{CO}_{2}}, \mathrm{pC} \mathrm{C}_{\mathrm{b}}\right)=(2,4,2)$.

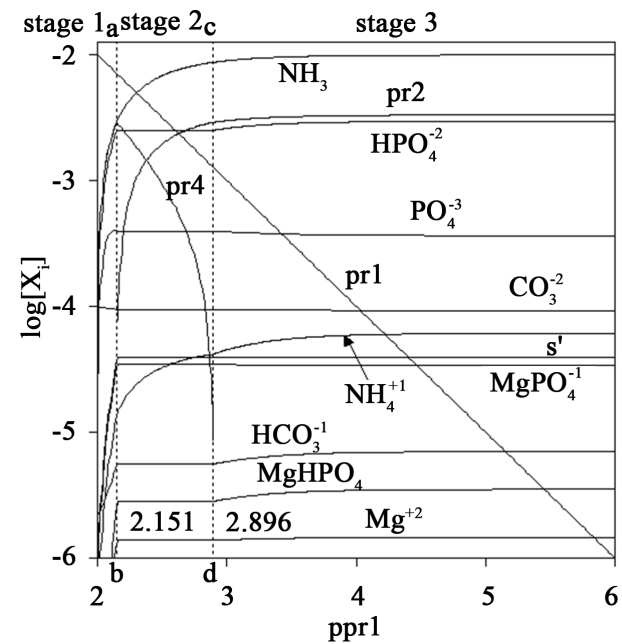

Figure 6. The $\log \left[\mathrm{X}_{\mathrm{i}}\right]$ vs. ppr1 relationships for indicated species $\mathrm{X}_{\mathrm{i}}$ at $\left(\mathrm{pC}_{0}, \mathrm{pC}_{\mathrm{CO} 2}, \mathrm{pC}_{\mathrm{b}}\right)=(2,4,2)$; s' is defined by Equation (14). 


$$
2 \mathrm{pr} 1+\mathrm{pr} 4=\mathrm{pr} 2+2 \mathrm{NH}_{3}+2 \mathrm{H}_{2} \mathrm{O}
$$

occurs up to total depletion of pr4 (at ppr1 $=2.896$ ), see Figure 6 . On the stage 3 , the reaction

$$
3 \mathrm{pr} 1+2 \mathrm{OH}^{-}=\mathrm{pr} 2+3 \mathrm{NH}_{3}+\mathrm{HPO}_{4}^{2-}+2 \mathrm{H}_{2} \mathrm{O}
$$

occurs up to total depletion of pr1, i.e., solubility product $\left(\mathrm{K}_{\mathrm{sp} 1}\right)$ for $\mathrm{pr} 1$ is not crossed. The $\mathrm{pH}$ changes, occurring during this process, are presented in Figure 7.

On the stage 1 , pr4 precipitates first, $\mathrm{pr} 1+2 \mathrm{OH}^{-}=\mathrm{pr} 4+\mathrm{NH}_{3}+\mathrm{HPO}_{4}^{2-}$, nearly from the very start of pr1 dissolution, up to ppr1 $=2.151$, where $\mathrm{K}_{\mathrm{sp} 2}$ is attained. Within the stage 2 , the solution is saturated toward pr2 and pr4. On this step, the reaction expressed by the notation $2 \mathrm{pr} 1+\mathrm{pr} 4=\mathrm{pr} 2+2 \mathrm{NH}_{3}+2 \mathrm{H}_{2} \mathrm{O}$ occurs up to total depletion of pr4 (at ppr1 $=2.896$ ). On the stage 3 , the reaction $3 \mathrm{pr} 1+2 \mathrm{OH}^{-}=\mathrm{pr} 2+3 \mathrm{NH}_{3}+\mathrm{HPO}_{4}^{-}+2 \mathrm{H}_{2} \mathrm{O}$ occurs up to total depletion of pr1, i.e., the solubility product $\mathrm{K}_{\mathrm{sp} 1}$ for $\mathrm{pr} 1$ is not crossed.

The curve s' (Figure 6) is related to the function

$$
\mathrm{s}^{\prime}=\mathrm{s}+\left[\mathrm{MgHCO}_{3}^{+}\right]+\left[\mathrm{MgCO}_{3}\right]
$$

where $s$ is expressed by Equation (6).

\subsection{Solubility of CuI in a Dynamic Redox System}

General Remarks

The system considered in this section is related to iodometric, indirect analysis of an acidified $\left(\mathrm{H}_{2} \mathrm{SO}_{4}\right)$ solution of $\mathrm{CuSO}_{4}$ [33]. On the preparatory step, an excess of $\mathrm{H}_{2} \mathrm{SO}_{4}$ is neutralized with $\mathrm{NH}_{3}$ until a blue colour appears, which is derived from $\mathrm{Cu}\left(\mathrm{NH}_{3}\right)_{\mathrm{i}}^{2+}$ complexes. Then $\mathrm{CH}_{3} \mathrm{COOH}$ is added, to attain a $\mathrm{pH}$ ca. 3.6. After subsequent introduction of an excess of KI solution, the mixture with $\mathbf{C u I}$ precipitate and dissolved iodine formed in the reactions:

$$
\begin{aligned}
& 2 \mathrm{Cu}^{2+}+4 \mathrm{I}^{-}=2 \mathrm{CuI}+\mathrm{I}_{2} \\
& 2 \mathrm{Cu}^{2+}+5 \mathrm{I}^{-}=2 \mathrm{CuI}+\mathrm{I}_{3}^{-}
\end{aligned}
$$

is titrated with $\mathrm{Na}_{2} \mathrm{~S}_{2} \mathrm{O}_{3}$ solution, until the reduction of iodine:

$$
\begin{aligned}
& \mathrm{I}_{2}+2 \mathrm{~S}_{2} \mathrm{O}_{3}^{2-}=2 \mathrm{I}^{-}+\mathrm{S}_{4} \mathrm{O}_{6}^{2-} \\
& \mathrm{I}_{3}^{-}+2 \mathrm{~S}_{2} \mathrm{O}_{3}^{2-}=3 \mathrm{I}^{-}+\mathrm{S}_{4} \mathrm{O}_{6}^{2-}
\end{aligned}
$$

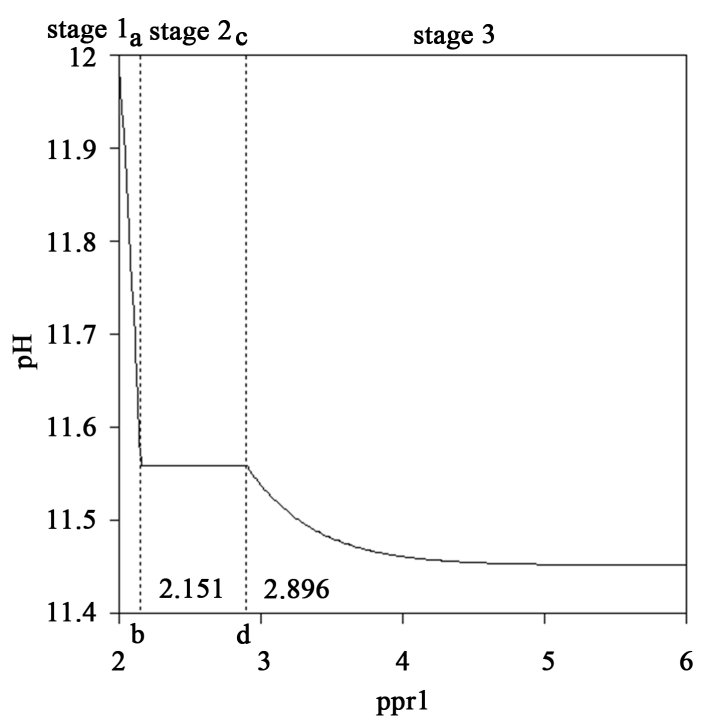

Figure 7. The $\mathrm{pH}$ vs. $\mathrm{ppr} 1=-\log [\mathrm{pr} 1]$ relationships plotted at $\left(\mathrm{pC}_{0}\right.$, $\left.\mathrm{pC}_{\mathrm{CO} 2}, \mathrm{pC}_{\mathrm{b}}\right)=(2,4,2)$. 
is completed. The reactions (17) and (18) proceed quantitatively in neutral or mildly acidic solutions, where the thiosulphate species are in a metastable state. In strongly acidic media, thiosulphuric acid disproportionates according to the scheme $\mathrm{H}_{2} \mathrm{~S}_{2} \mathrm{O}_{3}=\mathrm{H}_{2} \mathrm{SO}_{3}+\mathrm{S}$ [34].

The analytical procedure involved with this system consists of the following stages (all concentrations specified below are expressed in $\mathrm{mol} / \mathrm{L}$ ):

- stage 1: addition of $\mathrm{V} \mathrm{mL}$ of $\mathrm{NH}_{3}\left(\mathrm{C}_{1}\right)$ into $\mathrm{V}_{0} \mathrm{~mL} \mathrm{CuSO}_{4}\left(\mathrm{C}_{0}\right)+\mathrm{H}_{2} \mathrm{SO}_{4}\left(\mathrm{C}_{01}\right)$;

- stage 2: addition of $\mathrm{V} \mathrm{mL}$ of $\mathrm{CH}_{3} \mathrm{COOH}\left(\mathrm{C}_{2}\right)$ into $\mathrm{V}_{0}+\mathrm{V}_{\mathrm{N}} \mathrm{mL}$ of the resulting solution;

- stage 3: addition of $\mathrm{V} \mathrm{mL}$ of mol/L KI $\left(\mathrm{C}_{3}\right)$ into $\mathrm{V}_{0}+\mathrm{V}_{\mathrm{N}}+\mathrm{V}_{\mathrm{Ac}} \mathrm{mL}$ of the resulting solution;

- stage 4: addition of $\mathrm{V} m L$ of mol/ $/ \mathrm{Na}_{2} \mathrm{~S}_{2} \mathrm{O}_{3}(\mathrm{C})$ into $\mathrm{V}_{0}+\mathrm{V}_{\mathrm{N}}+\mathrm{V}_{\mathrm{Ac}}+\mathrm{V}_{\mathrm{K}} \mathrm{mL}$ of the resulting solution.

In this system, $\mathrm{CuSO}_{4}\left(\mathrm{C}_{0}\right)+\mathrm{H}_{2} \mathrm{SO}_{4}\left(\mathrm{C}_{01}\right)$ is considered as the sample tested; $\mathrm{V}_{\mathrm{N}}$ is the total volume of $\mathrm{NH}_{3}$ $\left(\mathrm{C}_{1}\right)$ added in stage $1 ; \mathrm{V}_{\mathrm{Ac}}$ is the total volume of $\mathrm{HAc}=\mathrm{CH}_{3} \mathrm{COOH}\left(\mathrm{C}_{2}\right)$ added in stage $2 ; \mathrm{V}_{\mathrm{K}}$ is the total volume of $\mathrm{KI}\left(\mathrm{C}_{3}\right)$ added in stage 3 . The non-redox stages $(1$ and 2$)$ are then followed by the redox stages ( 3 and 4$)$. In the calculations, the concentrations $[\mathrm{mol} / \mathrm{L}]: \mathrm{C}_{0}=0.01, \mathrm{C}_{01}=0.01, \mathrm{C}_{1}=0.25, \mathrm{C}_{2}=0.75, \mathrm{C}_{3}=2.0, \mathrm{C}_{4}=\mathrm{C}=0.1$, and volumes [mL]: $\mathrm{V}_{0}=100, \mathrm{~V}_{\mathrm{N}}=20, \mathrm{~V}_{\mathrm{Ac}}=40, \mathrm{~V}_{\mathrm{K}}=20$ were assumed. For further details-see [33].

To keep track of the gradual changes affected by addition of reagents in this system, it was assumed that the solutions of these reagents $\left(\mathrm{NH}_{3}, \mathrm{CH}_{3} \mathrm{COOH}, \mathrm{KI}, \mathrm{Na}_{2} \mathrm{~S}_{2} \mathrm{O}_{3}\right)$ are added according to titrimetric mode.

The solution on the $\mathrm{i}+1$-th step contains new $\mathrm{Cu}$-species in comparison with the $\mathrm{i}$-th stage $(\mathrm{i}=1,2,3)$. Maximal volumes on the abscissas for the stages 1,2 and 3 , are equal to $V_{N}, V_{A c}$ and $V_{K}$ respectively, assumed in the analysis; then e.g., $\log \left[\mathrm{CuCH}_{3} \mathrm{COO}^{+}\right]$at $\mathrm{V}=\mathrm{V}_{\mathrm{Ac}}$ in stage 2 is equal to $\log \left[\mathrm{CuCH}_{3} \mathrm{COO}^{+}\right]$at $\mathrm{V}=0$ in stage 3.

At each stage, the variable $\mathrm{V}$ is considered as a volume $[\mathrm{mL}]$ of the solution added, consecutively: $\mathrm{NH}_{3}$, $\mathrm{CH}_{3} \mathrm{COOH}, \mathrm{KI}$ and $\mathrm{Na}_{2} \mathrm{~S}_{2} \mathrm{O}_{3}$, although the true/factual titrant in this method is the $\mathrm{Na}_{2} \mathrm{~S}_{2} \mathrm{O}_{3}$ solution, added on the stage 4 .

The results of calculations are presented graphically in Figures 8-10.

It is a very interesting system, both from analytical and physicochemical viewpoints. Because the standard potential $\mathrm{E}_{0}=0.621 \mathrm{~V}$ for $\left(\mathrm{I}_{2}, \mathrm{I}^{-}\right)$exceeds $\mathrm{E}_{0}=0.153 \mathrm{~V}$ for $\left(\mathrm{Cu}^{2+}, \mathrm{Cu}^{+}\right)$, one could expect, at a first sight, the oxidation of $\mathrm{Cu}^{+}$by $\mathrm{I}_{2}$. However, such a reaction does not occur, due to the formation of sparingly soluble $\mathbf{C u I}$ precipitate $\left(\mathrm{pK}_{\mathrm{sp}}=11.96\right)$.

The solubility s $[\mathrm{mol} / \mathrm{L}]$ of $\mathbf{C u I}$ in this system is put in context with the speciation diagrams presented in Figure 8. This precipitate appears in the initial part of titration with $\mathrm{KI}\left(\mathrm{C}_{3}\right)$ solution (Figure 9(a)) and further it accompanies the titration, also in the stage 4 (Figure 9(b)). Within the stage 3, at $\mathrm{V} \geq 0.795 \mathrm{~mL}$, we have

$$
\begin{aligned}
\mathrm{s}=\mathrm{s}_{3}= & {\left[\mathrm{Cu}^{2+}\right]+\sum_{\mathrm{i}=1}^{4}\left[\mathrm{Cu}(\mathrm{OH})_{\mathrm{i}}^{+2-\mathrm{i}}\right]+\sum_{\mathrm{i}=1}^{4}\left[\mathrm{Cu}\left(\mathrm{NH}_{3}\right)_{\mathrm{i}}^{+2}\right]+\left[\mathrm{CuSO}_{4}\right]+\left[\mathrm{CuIO}_{3}^{+}\right] } \\
& +\sum_{\mathrm{i}=1}^{2}\left[\mathrm{Cu}\left(\mathrm{CH}_{3} \mathrm{COO}\right)_{\mathrm{i}}^{+2-\mathrm{i}}\right]+\left[\mathrm{Cu}^{+}\right]+\sum_{\mathrm{i}=1}^{3}\left[\mathrm{Cu}\left(\mathrm{NH}_{3}\right)_{\mathrm{i}}^{+}\right]
\end{aligned}
$$

and on the stage 4

$$
\mathrm{s}=\mathrm{s}_{4}=\mathrm{s}_{3}+\sum_{\mathrm{i}=1}^{2}\left[\mathrm{Cu}\left(\mathrm{S}_{2} \mathrm{O}_{3}\right)_{\mathrm{i}}^{+1-2 \mathrm{i}}\right]
$$

Small concentration of $\mathrm{Cu}^{+}$(Figure 8, stage 3) at a relatively high total concentration of $\mathrm{Cu}^{2+}$ determines the potential ca. $0.53-0.58 \mathrm{~V},\left[\mathrm{Cu}^{2+}\right] /\left[\mathrm{Cu}^{+}\right]=10^{\mathrm{A}(\mathrm{E}-0.153)}$, see Figure 9(a). Therefore, the concentration of $\mathrm{Cu}(+2)$ species determine relatively high solubility $\mathrm{s}$ in the initial part of stage 3 . The decrease in $\mathrm{s}$ value in further parts of the stage 3 is continued in the stage 4 , at $\mathrm{V}<\mathrm{V}_{\text {eq }}=\mathrm{C}_{0} \mathrm{~V}_{0} / \mathrm{C}=0.01 \times 100 / 0.1=10 \mathrm{~mL}$. Next, a growth in the solubility $\mathrm{s}_{4}$ at $\mathrm{V}>\mathrm{V}_{\mathrm{eq}}$ is involved with formation of thiosulfate complexes, mainly $\mathrm{CuS}_{2} \mathrm{O}_{3}^{-}$. The species $\mathrm{I}_{3}^{-}$ and $\mathrm{I}_{2}$ are consumed during the titration on the stage 4 (Figure 8(d)). A sharp drop of $\mathrm{E}$ value at $\mathrm{V}_{\text {eq }}=10 \mathrm{~mL}$ (Equation (8)) corresponds to the fraction titrated $\Phi_{\text {eq }}=1$.

The course of the E vs. V relationship within the stage 3 is worth a remark (Figure 10(a)). The corresponding curve initially decreases and reaches a "sharp" minimum at the point corresponding to crossing the solubility product for CuI. Precipitation of CuI (Equations (9) and (10)) starts after addition of $0.795 \mathrm{~mL}$ of $2.0 \mathrm{~mol} / \mathrm{L} \mathrm{KI}$ (Figure 10(c)). Subsequently, the curve increases, reaches a maximum and then decreases. At a due excess of the $\mathrm{KI}\left(\mathrm{C}_{3}\right)$ added on the stage $3\left(\mathrm{~V}_{\mathrm{K}}=20 \mathrm{~mL}\right)$, solid iodine $\left(\mathbf{I}_{2}\right.$, of solubility $0.00133 \mathrm{~mol} / \mathrm{L}$ at $\left.25^{\circ} \mathrm{C}\right)$ is not precipitated. 


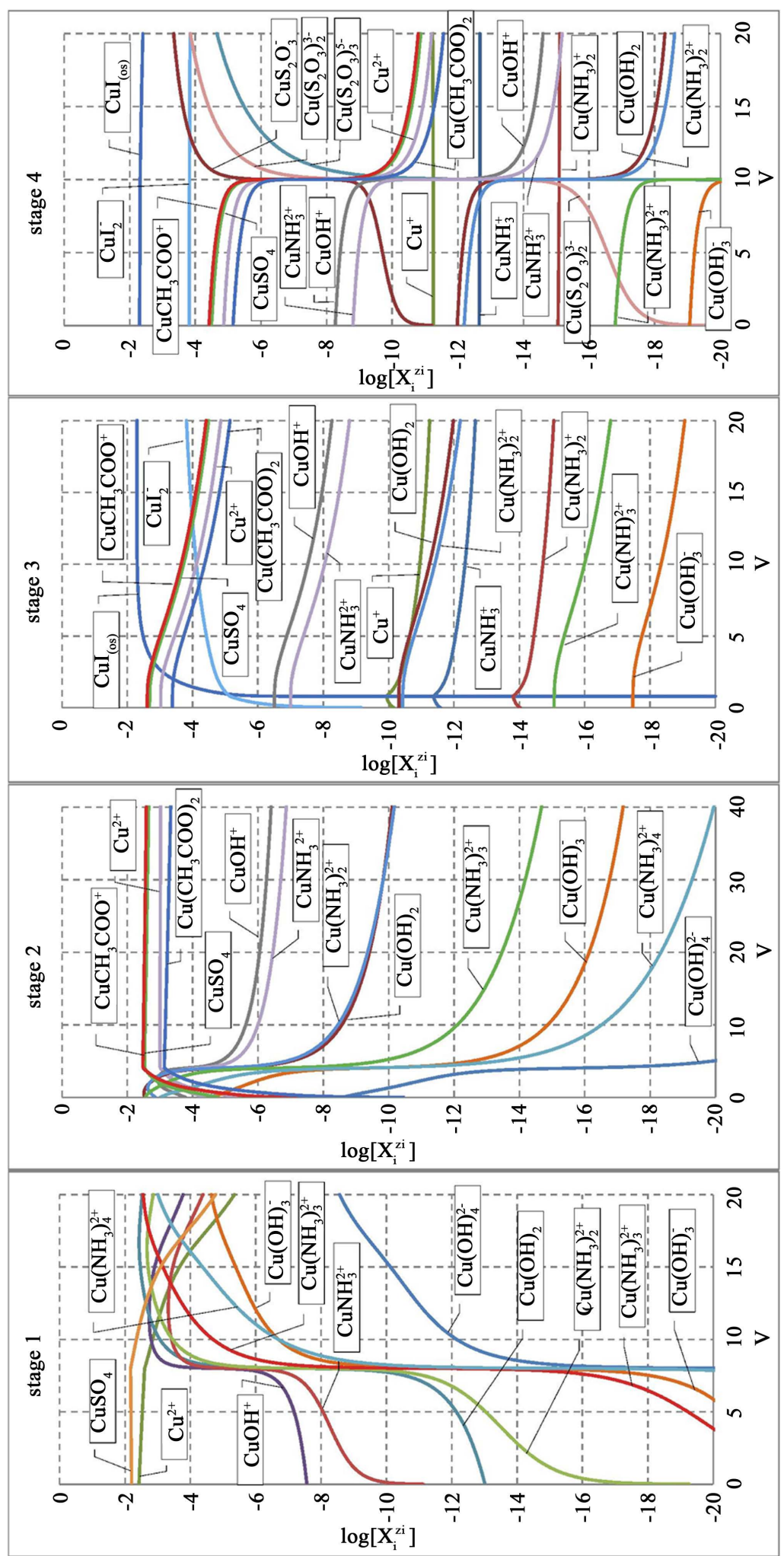

Figure 8. The speciation plots for indicated $\mathrm{Cu}$-species within the successive steps. The $\mathrm{V}$-values on the abscissas correspond to addition of $\mathrm{V} \mathrm{mL}$ of: $0.25 \mathrm{~mol} / \mathrm{L} \mathrm{NH}_{3}$ (step 1); $0.75 \mathrm{~mol} / \mathrm{L} \mathrm{CH}_{3} \mathrm{COOH}$ (step 2); $2.0 \mathrm{~mol} / \mathrm{L} \mathrm{KI}$ (step 3); $0.1 \mathrm{~mol} / \mathrm{L} \mathrm{Na}_{2} \mathrm{~S}_{2} \mathrm{O}_{3}$ (step 4). For more details—see text. 


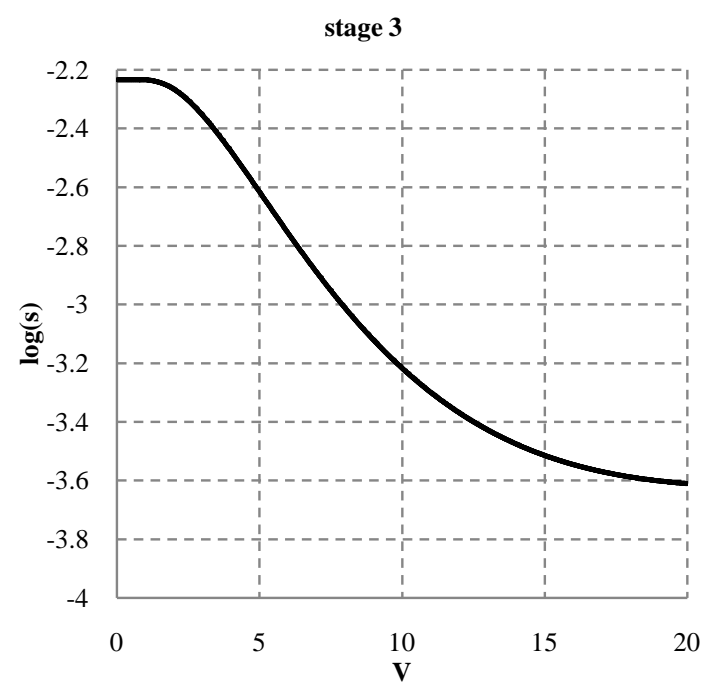

(a)

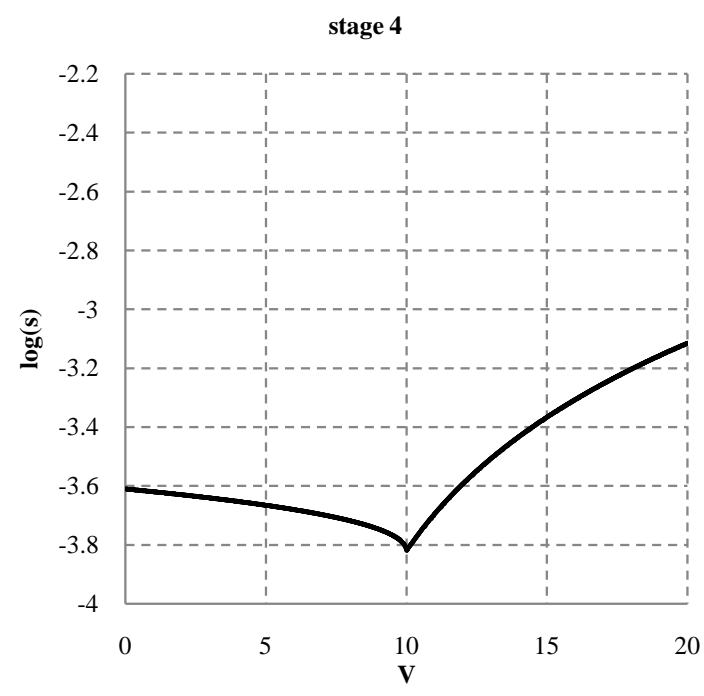

(b)

Figure 9. Solubility s of CuI within the stage: (a) 3; and (b) 4.

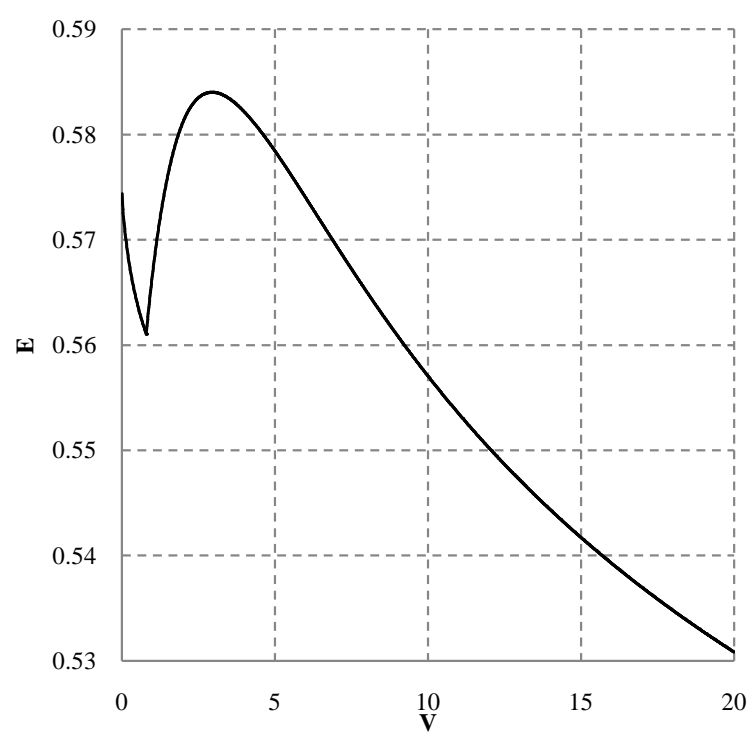

(a)

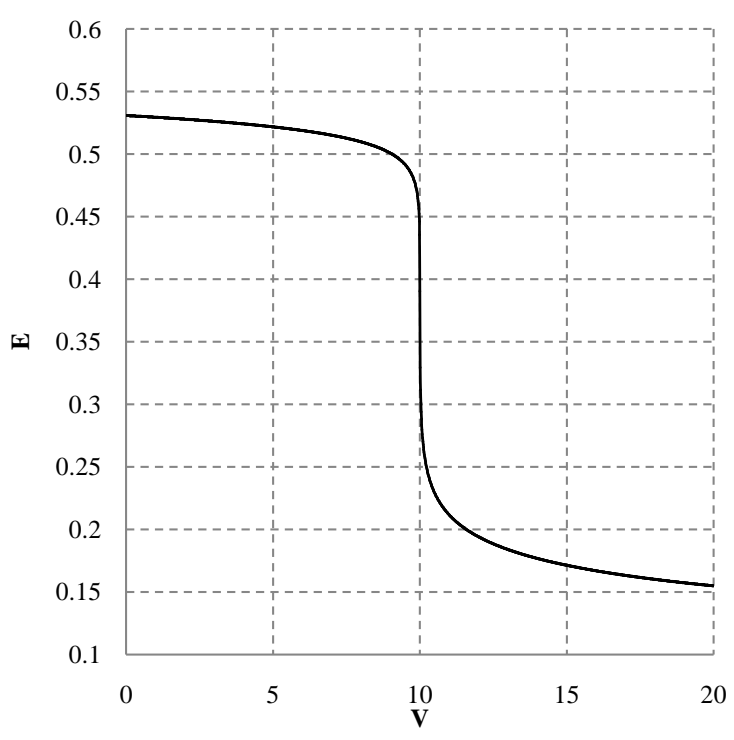

(b)

Figure 10. Plots of E vs. V within the stage: (a) 3; and (b) 4.

The solubility curves are related to an excess of $\mathrm{KI}$ as the precipitating agent; such a case occurs at $\mathrm{V} \geq$ $\mathrm{C}_{0} \mathrm{~V}_{0} / \mathrm{C}_{3}=0.5 \mathrm{~mL}$. Because $0.5<0.795$, it means that the stoichiometric excess includes herein the entire V-range where $\mathbf{C u I}$ is the equilibrium solid phase, i.e. $\mathrm{V} \geq 0.795$.

\section{Final Comments}

The paper criticizes the description of two-phase electrolytic systems, of different degree of complexity, based on stoichiometric reaction notation (Equation (1) or (2)). Even in relatively simple cases, this scheme leads to an incorrect assessment of the real solubility, s.

Instead of that (schematic) approach to the issue, the calculations of s, based on the matter and charge conservation, with all attainable physicochemical knowledge involved in complete set of equilibrium constants related to the system in question, is suggested. The solubility $\mathrm{s}$ is expressed as total concentration of all species formed by a given element in the solution in equilibrium with a sparingly soluble precipitate, not only the spe- 
cies specified in the related reaction notation, as were practiced hitherto. Diversity of $\mathrm{K}_{\mathrm{sp}}$ value that depends on the dissociation reaction notation, disqualifies the calculation of $\mathrm{s}^{*}$ on the basis of $\mathrm{K}_{\mathrm{sp}}$ value. Generalizing, nearly all approximate formulae applied for calculation of solubility on the basis of stoichiometric dissociation reactions are worthless.

In relatively simple systems [5]-[7], the procedure based on calculation of $\mathrm{pH}=\mathrm{pH}_{0}$ value zeroing charge balance equation can be applied for calculation of concentrations for all the species involved in expression for solubility s value. More complex two-phase systems require a calculation procedure based on iterative computer programs, offered e.g. by MATLAB [7], applied to algorithms based on principles of the Generalized Approach to Electrolytic Systems (GATES). The MATLAB was applied, among others, to monitor processes in non-equilibrium systems; such systems are exemplified by the system obtained after introduction of struvite into water, or to a solution with pre-assumed composition. On the basis of calculations and graphical presentation of the results thus obtained, one can track phase transitions in the system, assuming quasistatic course of the relevant processes, realized under isothermal conditions.

\section{References}

[1] Dirkse, T.P., Michałowski, T., Akaiwa, H. and Izumi, F. (1986) Copper, Silver, Gold and Zinc, Cadmium, Mercury Oxides and Hydroxides. Solubility Data Series, Vol. 23, Oxford. https://openlibrary.org/books/OL17913816M/Copper_silver_gold_and_zinc_cadmium_mercury_oxides_and_hydroxides

[2] Kotrly, S. and Sucha, L. (1985) Handbook of Chemical Equilibria in Analytical Chemistry. Ellis Horwood Series in Analytical Chemistry, Prentice Hall.

[3] Michałowski, T. (2001) Calculations in Analytical Chemistry with Elements of Computer Programming (in Polish). PK, Cracow. http://suw.biblos.pk.edu.pl/resourceDetails\&rId=3974

[4] Michałowska-Kaczmarczyk, A.M. and Michałowski, T. (2014) Calculation of Solubility of Oxyquinolinates. Journal of Analytical Sciences, Methods and Instrumentation, 4, 71-79. http://www.scirp.org/journal/PaperInformation.aspx?PaperID=49423\#.VGJQ7GdvHFw

[5] Michałowska-Kaczmarczyk, A.M. and Michałowski, T. (2015) Solubility Product Challenge. Analytical and Bioanalytical Chemistry, 407, 1789-1791. http://dx.doi.org/10.1007/s00216-014-8407-2

[6] Michałowska-Kaczmarczyk, A.M. and Michałowski, T. (2015) Solution to the Solubility Product Challenge. Analytical and Bioanalytical Chemistry, 407, 4877-4878. http://dx.doi.org/10.1007/s00216-015-8713-3

[7] Michałowski, T. (2011) Application of GATES and MATLAB for Resolution of Equilibrium, Metastable and NonEquilibrium Electrolytic Systems, Chapter 1, pp. 1-34. In: Michałowski, T., Ed., Applications of MATLAB in Science and Engineering, InTech-Open Access Publisher in the Fields of Science, Technology and Medicine, Rijeka. http://www.intechopen.com/books/show/title/applications-of-matlab-in-science-and-engineering

[8] Gordus, A.A. (1991) Chemical Equilibrium. VIII. Precipitates. Journal of Chemical Education, 68, 927-930. http://dx.doi.org/10.1021/ed068p927

[9] Clark, R.W. and Bonicamp, J.M. (1991) The Ksp-Solubility Conundrum. Journal of Chemical Education, 75, $182-185$.

[10] http://chemwiki.ucdavis.edu/Physical_Chemistry/Equilibria/Solubilty/Solubility/Calculations_Involving_Solubility_Pr oducts

http://www.chemteam.info/Equilibrium/Calc-Ksp-FromMolSolub.html http://formulas.tutorvista.com/chemistry/solubility-formula.html

[11] Michałowska-Kaczmarczyk, A.M., Asuero, A.G. and Michałowski, T. (2015) "Why Not Stoichiometry” versus “Stoichiometry-Why Not?” Part I. General Context. Critical Reviews in Analytical Chemistry, 45, 166-188. http://dx.doi.org/10.1080/10408347.2014.937852

[12] Michałowska-Kaczmarczyk, A.M. and Michałowski, T. (2014) Evaluation of Transition Points between Different Solid Phases in Aqueous Media. Journal of Analytical Sciences, Methods and Instrumentation (JASMI), 4, 87-94. http://www.scirp.org/journal/PaperInformation.aspx?PaperID=49567\#.VGOZo2dvHFw http://dx.doi.org/10.4236/jasmi.2014.43012

[13] Michałowski, T. and Pietrzyk, A. (2006) A Thermodynamic Study of Struvite + Water System. Talanta, 68, 594-601. http://dx.doi.org/10.1016/j.talanta.2005.04.052

[14] Beilstein, F. and Grosset, T. (1890) Ueber die Bestimmung der freien Schwefelsäure in der Schwefelsauren Thonerde. Zeitschrift für Analytische Chemie, 29, 73-78. http://dx.doi.org/10.1007/BF01367030

[15] Doyle, J.D. and Parsons, S.A. (2002) Struvite Formation, Control and Recovery. Water Research, 36, 3925-3940. http://dx.doi.org/10.1016/S0043-1354(02)00126-4 
[16] Komiyama, T., Niizuma, S., Fujisawa, E. and Morikuni, H. (2013) Phosphorus Compounds and Their Solubility in Swine Manure Compost. Soil Science and Plant Nutrition, 59, 419-426. http://dx.doi.org/10.1080/00380768.2013.789397

[17] http://www2.bakersfieldcollege.edu/wcooper/HW\%20Answers_Spring_09/Chapter\%2017\%20Homework\%20Answer s.pdf

[18] http://www.britannica.com/topic/nickel-dimethylglyoxime

[19] https://en.wikipedia.org/wiki/Dimethylglyoxime

[20] Gazda, D.B., Fritz, J.S. and Porter, M.D. (2004) Determination of Nickel(II) as the Nickel Dimethylglyoxime Complex Using Colorimetric Solid Phase Extraction. Analytica Chimica Acta, 508, 53-59. http://dx.doi.org/10.1016/j.aca.2003.11.044

[21] Michałowski, T., Nizińska-Pstrusińska, M., Sztark, W. and Baterowicz, A. (2002) Laboratory Trainings in Analytical Chemistry. PK, Cracow. (In Polish) https://suw.biblos.pk.edu.pl/resources/i3/i9/i7/i5/r3975/MichalowskiT_CwiczeniaLaboratoryjne.pdf

[22] http://www.google.ca/patents/US4621080

[23] http://www.chemicalland21.com/lifescience/phar/COPPER-8-QUINOLATE.htm

[24] http://www.inchem.org/documents/iarc/vol15/copper8hydroxyquinoline.html

[25] https://en.wikipedia.org/wiki/8-Hydroxyquinoline

[26] Inczédy, J. (1976) Analytical Applications of Complex Equilibria. Ellis Horwood, Chichester.

[27] http://chemlab.truman.edu/CHEM222manual/pdf/nickelgrav.pdf

[28] Michałowski, T. (1982) Solubility Diagrams and Their Use in Gravimetric Analysis. Chemia Analityczna, 27, 39-49.

[29] Stratful, I., Scrimshaw, M.D. and Lester, J.N. (2001) Conditions Influencing the Precipitation of Magnesium Ammonium Phosphate. Water Research, 35, 4191-4199. http://dx.doi.org/10.1016/S0043-1354(01)00143-9

[30] Golubev, S. (2000) Solubility of Struvite in Seawater. Journal of Conference Abstracts, 5, 449. http://www.the-conference.com/JConfAbs/5/449.pdf

[31] Demirer, G.N. (2011) Struvite Precipitation from Anaerobic Co-Digestion Residues of Poultry Manure and Maize Silage. XXXIV CIOSTA CIGR V Conference 2011. http://www.nas.boku.ac.at/fileadmin/data/H03000/H93000/H93100/CIOSTA_Presentations/yilmazel.pdf

[32] Shalaby, M.S., El-Rafie, S., Hamzaoui, A. and M’nif, H.A. (2015) Modeling and Optimization of Phosphate Recovery from Industrial Wastewater and Precipitation of Solid Fertilizer Using Experimental Design Methodology. Chemical and Biochemical Engineering Quarterly, 29, 35-46. http://dx.doi.org/10.15255/CABEQ.2014.2107

[33] Michałowska-Kaczmarczyk, A.M., Michałowski, T., Toporek, M. and Asuero, A.G. (2015) "Why Not Stoichiometry” versus “Stoichiometry-Why Not?” Part III, Extension of GATES/GEB on Complex Dynamic Redox Systems. Critical Reviews in Analytical Chemistry, 45, 348-366. http://dx.doi.org/10.1080/10408347.2014.953673

[34] Steudel, R. (Ed.) (2003) Elemental Sulfur and Sulfur-Rich Compounds, II, Topics in Current Chemistry. SpringerVerlag, Berlin. http://dx.doi.org/10.1007/b12115 